\title{
Obstructive Sleep Apnea destabilizes myocardial repolarization homogeneity.
}

\section{Aleksandra Jarecka-Dobroń, MD, PhD ${ }^{1}$, Wojciech Braksator, MD, $\mathrm{PhD}^{2}$, Pawel Chrom, MD, $\mathbf{P h D}^{3}$.}

${ }^{1}$ Internal Ward, Medical Center of Nowy Dwór Mazowiecki, in Nowy Dwór Mazowiecki, Miodowa str 2, 05-100 Nowy Dwór Mazowiecki, Poland, a.e.jarecka@gmail.com. CORRESPONDING AUTHOR

${ }^{2}$ Department of Sports Cardiology and Noninvasive Cardiac Imaging, Medical University of Warsaw, Brodnowski Hospital, Kondratowicza str 8, 03-242 Warsaw, Poland

${ }^{3}$ Medstat Solutions, Hoża str 86/410, 00-682 Warsaw, Poland

Key words: obstructive sleep apnea, obesity, QT interval, QT variability, heart muscle repolarization. 


\begin{abstract}
Background:

Literature shows that patients with obesity and Obstructive Sleep Apnea (OSA), both occurring independently, are more likely to develop cardiovascular diseases and sudden cardiac death (SCD). Assuming that ventricular depolarization is more stable than repolarization then QT interval parameters may be used for heart muscle repolarization assessment for those groups of patients.
\end{abstract}

Methods:

There were 121 patients included in the study, both - women and men, aging from 3565 with visceral obesity. Only healthy patients were included - the ones who were not treated for any chronic disease, taking QT elongating drugs, or were not treated with Continuous Positive Airway Pressure (CPAP) therapy at that time.

Results:

OSA was diagnosed in 70 patients (including 41 male). A statistically significant difference for QT interval parameters between OSA positive and negative patients was found ( $\mathrm{p}<0.001$ for all variables). No difference for QTc max or for QT interval parameters between groups of patients with different OSA severity degrees was found. A correlation between QTVi2 and QTVi3 ( $\mathrm{p}=0.008$ ) and between polygraphy specific parameters and QTc max, QTVi2 and QTVi3 was found.

\title{
Conclusions:
}

OSA has a negative influence on heart muscle repolarization processes by increasing QTV and QTVi values, without such an impact on QTc max interval among patients with visceral obesity. A temporary intensification of OSA causes additional increase of QTVi value. OSA severity degree expressed by specific parameters taken from polygraphic examination prolongs QTc max and increases QTV and QTVi values.

1. What is the key question?

Does Obstructive Sleep Apnea destabilize heart muscle repolarization time heterogeneity expressed by QT interval assessment parameters (QTc, QTV, QTVi)?

2. What is the bottom line?

Obstructive Sleep Apnea occurrence presents an essential negative influence on heart muscle repolarization time, as heterogeneity by QTV and QTVi values increase, while QTc max interval remains unaffected among patients with visceral obesity.

3. Why to read on? 
Knowing that obesity and Obstructive Sleep Apnea (occurring separately) increase the risk of sudden cardiac death, cardiovascular risk evaluation becomes an important point for obese, OSA positive patient's care.

\section{Introduction:}

Visceral obesity is a condition in which abnormally high volume of adipose tissue is deposited in the abdominal region, especially inside the peritoneal cavity and between internal organs. According to the World Health Organization (WHO) and the International Diabetes Federation (IDF) definition, it is diagnosed if waist circumference is more than 94 $\mathrm{cm}$ (for men) and more than $80 \mathrm{~cm}$ (for women). Obstructive Sleep Apnea (OSA), which occurrence is closely linked to obesity, is characterized by numerous episodes of apnea and hypopnea during sleep caused by temporal, partial or total, upper airways obstruction and it is recognized as an independent cardiovascular risk $(1,2)$. Obesity has been linked to heart muscle repolarization disorders expressed as QT interval elongation (3). A provocative influence of OSA on heart rhythm disturbances has been frequently researched in the past decade $(4,5)$. However, only a few reports in the literature mention that OSA may be connected with acquired QT interval elongation (5). Moreover, observations of Sudden Cardiac Death (SCD) increased risk among OSA patients have been described in literature since 1970.

It has been commonly accepted to regard QT interval as an estimation of heart muscle repolarization. QT interval elongation may provoke life threatening ventricular arrhythmias and SCD. QT interval duration shows spontaneous, slight fluctuations in every heartbeat cycle. This phenomenon is specified as QT interval variability (QTV). QTV is primarily a parameter that enables variability of repolarization processes assessment. In standard conditions, at stable heart rhythm frequency, QTV value is low. The best prognostic value, beyond the most frequently used maximum QTc, have QTV, QTV index (QTVi) and QTV assessed in Heart Rate Variability (HRV) low frequency (LF) and high frequency (HF) bands $\left(\mathrm{QTV}_{\mathrm{LF}}, \mathrm{QTV} \mathrm{HF}\right)(6)$. A wide clinical importance of the abovementioned parameters has been confirmed in numerous studies and their usage is recommended by European Cardiology Society (ESC) (6-15). The problem of dependence between OSA severity degree and QT interval assessment parameters changes has not been analyzed in literature by using any indicator recommended by European Society of Cardiology (ESC).

\section{Methods}

The current study was a prospective, observational clinical trial performed between September 2016 and August 2019 at a single-center institution specializing in treatment of patients with obstructive sleep apnea. The inclusion criteria were as follows: (1) gender: female or male, (2) age 35-65 years old, (3) visceral obesity, (4) lack of acute or chronic diseases that may have an influence on rhythm or conduction disorders, (5) not undergoing Continuous Positive Airway Pressure therapy (CPAP) or taking drugs that have or may have 
medRxiv preprint doi: https://doi.org/10.1101/2020.07.22.20159657; this version posted July 24, 2020. The copyright holder for this preprint

an influence on QT interval duration (according to Credible Meds list (16)), (6) not consuming grapefruits or grapefruit juice for at least 2 weeks before Holter-ECG examination. Patients, who met all inclusion criteria, underwent subject and physical examination, an over-night Holter-ECG, and polygraphy. After getting all results they were checked against the following exclusion criteria: 1) revealing that information about patient's chronic illness or drugs therapy was obfuscated, revealing increased fasting serum glucose concentration. It was strongly recommended to every patient to visit their GP for further diagnostics, 2) revealing any important deviation in physical examination i.a. blood pressure taken twice at the visit $\geq 140 / \geq 90 \mathrm{mmHg}$, 3) revealing, upon Holter ECG examination, tachycardia or too numerous artifacts making QT interval assessment incredible, 4) too short total sleep time ( $<6$ hours) registered on polygraphy.

Out of 187 consecutive patients meeting the inclusion criteria, 66 patients met at least one exclusion criterion, leaving 121 patients for the study analyses.

Enrolled patients were asked questions about general frame of mind, daytime and nighttime symptoms that may suggest OSA (according to Epworth Sleepiness Scale (17)). All patients were fully physically examined. Neck and waist circumference were measured according to STEPwise Approach to Surveillance (STEPS) by WHO (18). Upon subject examination (snoring and choking feeling during the sleep) a corrected neck circumference was calculated.

Polygraphy was conducted using MED Recorder device by Infoscan company according to AASM guidelines (19). The device registered blood saturation, heart rate, airflow, chest and abdomen movements, body position, snoring and single lead ECG. OSA was diagnosed according to AASM definition (20): in every patient with Respiratory Disturbance Index (RDI) $\geq 5 /$ hour and with concomitant OSA sings (Epworth Sleepiness Scale $\geq 11$ pts) or with RDI $\geq 15 /$ hour. The minimum time of analyzed data without artifacts had to last at least $6 \mathrm{~h}$.

A Holter-ECG examination was conducted using DMS 300-3A device by Oxford company suitable for Cardioscan 10 system. Registration was made simultaneously with polygraphy, during the night. Chosen QT interval assessment parameters were evaluated upon partially automatically analyzed fragments of ECG records. Only nighttime ECG records were analyzed due to maximum comparability (similar patient's physical activity and minimized, because of limited body movements, artifacts). Moreover, the study aimed to assess a heart's activity simultaneous to sleep breathing disorders. Only ECG strips with constant heart rate, optimally within 50-70/min limits, were chosen due to the minimum impact of such heart rate on QT interval correction formula. QTc data was calculated upon Bazett's formula. QTV and QTVi were calculated upon Berger's formula.

Described above group of patients was divided into groups:

1. Patients with visceral obesity without OSA, 
2. Patients with visceral obesity with OSA.

Group of patients in which OSA was diagnosed was additionally divided into three subgroups, depending on the breathing disorders severity degree:

a) OSA of $1^{\text {st }}$ degree $(\mathrm{RDI} \geq 5$ and $<15)$,

b) OSA of $2^{\text {nd }}$ degree (RDI $\geq 15$ and $\left.<30\right)$,

c) OSA of $3^{\text {rd }}(\mathrm{RDI} \geq 30)$.

QT interval assessment parameters were divided into groups:

1. assessment of data of patients only with visceral obesity (no OSA) (QTV1, QTVi1),

2. assessment of data of patients with visceral obesity and OSA, data taken from OSA intervals of minimum severity or from intervals without breathing disorders (QTV2, QTVi2),

3. assessment of data of patients with visceral obesity and OSA, data taken from OSA intervals of maximum severity (QTV3, QTVi3).

Descriptive statistics included means and standard deviations (SDs) (or medians and ranges for non-normally distributed or ordinal data) for continuous variables and frequencies and percentages for categorical variables. Normality assumption was assessed using the Shapiro-Wilk test and homogeneity of variance was assessed using the Levene's test. For independent variables measured in a continuous scale, the student's t-test (or the MannWhitney test) was used to compare differences between two analyzed groups, while the analysis of variance (ANOVA) (or the Kruskal-Wallis test) was used to compare differences between more than two analyzed groups. In the latter case, the Bonferroni correction (or the Dunn-Bonferroni correction) was used in a post-hoc testing. For dependent variables measured in a continuous scale, the paired-sample t-test (or the Wilcoxon test) was used to evaluate differences between measures performed at two timepoints. For independent variables measured in a nominal scale, the chi-squared test (or the Fisher's exact test) was used to compare differences between two groups. A univariate linear regression was used to assess the influence of RDI on QTc max, QTV and QTVi. Generalized estimating equations (GEE), with identity as a linking function and exchangeable structure of within-group correlation matrix, were used in a multivariate longitudinal analysis covering two timepoints (at no/minimal signs of apnea and at maximum exacerbation of apnea) to evaluate the impact of several clinical factors on QTc max, QTV and QTVi in patients with diagnosed OSA.

\section{Results}

1. Clinical characteristic of examined patients.

Overall characteristics of the examined population disaggregated into groups with and 
medRxiv preprint doi: https://doi.org/10.1101/2020.07.22.20159657; this version posted July 24, 2020. The copyright holder for this preprint

without OSA, with the analysis of dependence of OSA occurrence on changes in QT interval assessment parameters are presented in Table 1. Population of patients who were diagnosed with OSA numbered 70 people, including 41 men.

\section{Relationship between OSA occurrence and QT interval.}

A comparative analysis of QTc max values from the whole Holter-ECG record in OSA positive and OSA negative groups was performed. Arithmetic mean, standard error (SE) and $95 \%$ confidence interval $(\mathrm{CI})$ of QTc max are presented in Figure 1. Groups did not differ significantly for QTc $\max (t=-0.484$, degrees of freedom $(d f)=119, p=0.630)$.

A significant correlation for QTc max 1 on QTc max 2, or for QTc max 1 on QTc $\max 3(\mathrm{p}=0.6 ; \mathrm{p}=0.84)$ was not observed. However, a significant correlation for QTV1 on QTV2 as well as for QTV1 on QTV3 was found $(\mathrm{p}<0.001 ; \mathrm{p}<0.001)$. A significant correlation for QTVi1 on QTVi2 as well as QTVi1 on QTVi3 was found $(p<0.001 ; p<0.001)$.

\section{Relationship between OSA severity degree and QT interval assessment parameters.}

Analysis results of the correlation between OSA' severity degree and changes in QT interval assessment parameters are displayed in Table 2.

A comparative analysis of QTc max values from the whole Holter-ECG record between patient groups with $1^{\text {st }}, 2^{\text {nd }}$ and $3^{\text {rd }}$ severity degree was performed. Arithmetic mean, SE and 95\% CI QTc max are presented in Figure 2. No significant difference in QTc max values of each group was shown $(\mathrm{F}=1.355, \mathrm{df}=2, \mathrm{p}=0.265)$.

No significant difference was found for QTc max taken from ECG record with breathing disorders of a minimum severity or without them (QTc max2) between groups of different OSA severity degrees $(\mathrm{p}=0.260)$. No significant difference was found for QTc max taken from ECG record with breathing disorders of a maximum severity (QTc max3) between groups of different OSA severity degrees $(\mathrm{p}=0.430)$.

A univariate analysis for RDI influence on QTC max taken from the whole HolterECG record assessment was performed. A scatter plot with RDI variable on the $\mathrm{X}$ axis and QTc max variable on the $\mathrm{Y}$ axis are presented on Figure 3. Regression results with QTc max variable as a dependent variable and RDI variable as an independent variable are shown in the Table 2. It was demonstrated within the regression that RDI increase by 1 per hour causes a statistically significant QTc max elongation by $0.187 \mathrm{~ms}$.

No significant difference was found for QTV taken from ECG records with breathing disorders of a minimum severity or without them (QTV2) between groups of different OSA severity degrees $(\mathrm{p}=0.270)$. No significant difference was found for QTV taken from ECG records with breathing disorders of a maximum severity (QTV3) between groups of different OSA severity degrees $(\mathrm{p}=0.10)$.

A single factor analysis for RDI influence on QTV assessment was conducted. 
medRxiv preprint doi: https://doi.org/10.1101/2020.07.22.20159657; this version posted July 24, 2020. The copyright holder for this preprint

Regression results with QTV variable as a dependent variable and RDI variable as an independent variable are presented in Table 3. It is visible within the regression that RDI increase by 1 per hour causes a statistically significant QTV increase by $0.039 \mathrm{~ms}$.

No significant difference was found for QTVi taken from ECG record with breathing disorders of a minimum severity or without them (QTVi 2) between groups of different OSA severity degrees $(\mathrm{p}=0.150)$. No significant difference was found for QTVi taken from ECG records with breathing disorders of a maximum severity (QTVi 3) between groups of different OSA severity degrees $(\mathrm{p}=0.970)$.

A univariate analysis for RDI influence on QTVi assessment was conducted. Regression results with QTVi variable as a dependent variable and RDI variable as an independent variable are presented in Table 4. It was demonstrated within the regression that RDI increase by 1 per hour causes a statistically significant QTVi increase by $0.011 \mathrm{~ms}$.

Comparative characteristics of groups with different OSA severity degrees is presented in Table 5.

\section{Relationship between QT interval and temporary OSA intensification.}

Analysis results of OSA influence on QT interval assessment parameters depending on a temporary OSA intensification are presented in Table 6.

No significant difference was found for QTc max taken from ECG record with breathing disorders of a minimum severity or without them (QTc max2) and QTc max taken from ECG record with breathing disorders of a maximum severity (QTc max 3) of the same patient $(\mathrm{p}=0.910)$.

No significant difference was found for QTV taken from ECG record with breathing disorders of a minimum severity or without them (QTV 2) and QTV taken from ECG record with breathing disorders of a maximum severity (QTV 3$)$ of the same patient $(\mathrm{p}=0.060)$.

A significant difference was found for QTVi taken from ECG record with breathing disorders of a minimum severity or without them (QTVi 2) and QTV taken from ECG record with breathing disorders of a maximum severity (QTVi 3) of the same patient $(\mathrm{p}=0.008)$.

It is noticeable that a percentage share of male and female sex among groups of patients with and without OSA with a critically elongated QTc max interval diagnosed (for each sex $>500 \mathrm{~ms}$ ) occurs.

The analysis is presented in the Figure 4.

\section{Relationship between polygraphic parameters and QT interval.}

There was a multivariate linear regression conducted for QT interval assessment parameters variability evaluation, taken from the whole overnight Holter-ECG examination and from chosen ECG record fragments, registered simultaneously to breathing disorders of a 
minimum severity degree or without them as well as from chosen ECG record fragments, registered simultaneously to breathing disorders of a maximum severity degree. Regression assessed variability of those parameters according to variability of chosen polygraphic parameters. With this end in view, three models including variables from polygraphic examination that potentially could interfere with QTc max, QTV and QTVi values, were created. In the first model polygraphic parameters such as: RDI (Respiratory Disturbance Index), AI (Apnea Index), ODI4\% (number of episodes of at least 4\% saturation decrease), T90 (time of the examination with hypoxia below 90\%), $\mathrm{SpO}_{2}$ min (minimum registered saturation value), $\mathrm{SpO}_{2}$ av (average registered saturation value) with QTc max interval assessment taken from the whole overnight Holter-ECG record were considered. In the second model the same parameters from polygraphic examination with Holter-ECG parameters taken from simultaneous episodes of breathing disturbances of a minimum severity degree or without them (QTc max 2, QTV 2, QTVi 2) were considered. In the third model, above parameters from polygraphic examination with Holter-ECG parameters taken from simultaneous episodes of breathing disturbances of a maximum severity degree (QTc max 3, QTV 3, QTVi 3) were taken into consideration.

A statistically significant difference for the above chosen polygraphic parameters (RDI, ODI4\%) and QTc max was found ( $\mathrm{p}=0.004 ; \mathrm{p}=0.005)$. Also a statistically significant difference for chosen polygraphic parameters (RDI, AI, $\mathrm{SpO}_{2}$ min, ODI4\%) and QTc max 2 was found $(\mathrm{p}=0.009 ; \mathrm{p}=0.002 ; \mathrm{p}=0.010$ ). From the same period of time (of minimum or lack of breathing disorders) a statistically significant difference for chosen polygraphic parameters $\left(\mathrm{SpO}_{2}\right.$ min, $\mathrm{SpO}_{2}$ av, T90) and QTVi2 was also found ( $\left.\mathrm{p}=0.030 ; \mathrm{p}=0.040 ; \mathrm{p}=0.040\right)$. A statistically significant difference for one polygraphic parameter (RDI) and QTc max 3 $(\mathrm{p}=0.040)$ as well as for RDI, AI, ODI4\% and QTV3 was found $(\mathrm{p}=0.030 ; \mathrm{p}=0.0300$; $\mathrm{p}=0.02$ ). Moreover, all results appeared to be independent of age and BMI. Analysis results are presented in the Table 7.

\section{Discussion}

So far only a few studies evaluated the visceral fat tissue's potential to disturb heart muscles electrophysiological functioning (21-23). Results of those studies, however taken on small groups of patients, may be indicative for a negative influence of biochemical factors released to the bloodstream by visceral fat tissue on the heart muscle. What is more, only a few researchers have decided to study a correlation between OSA and heart muscle repolarization disturbances. An important, pathological relationship between those two diseases was observed by Baumert et al. (24).

All patients had a sinus rhythm of a comparable rate, about 68-69/min. Presented in the Table 1 basic, anthropometric parameters characterizing the studied population are similar to those described by other researchers $(21,22,25,26)$. Significantly more patients with OSA of a severe degree were men. Also, OSA positive patients were statistically older and more obese (BMI, waist and neck circumference). It emphasizes the importance of tests for OSA at least among middle-aged, obese men. Studied groups heterogeneity, in terms of the above mentioned parameters, is a result of the conducted study model. A significant difference in 
heart rate between OSA positive and negative groups was not shown, which was one of the methodological assumptions - it enabled a reliable assessment of QT and QTc values from Holter-ECG records. Results of so far published studies regarding OSA usually took into account only patients with at least moderate OSA severity degree (most with a severe degree) and did not compare the results with a validation cohort or studied groups were very small.

In the conducted analysis the influence of OSA on QTc interval (taken from the whole overnight Holter-ECG record) elongation was not confirmed. However, the regression model showed that RDI increase by 1 event/hour causes a significant QTc interval elongation. A significant relationship between OSA and increase of QTV and QTVi was confirmed. Also, the regression model confirmed that RDI increase by 1 event/hour causes a statistically significant QTV and QTVi increase. No differences in QT parameters in groups of OSA patients of a different severity degree were shown. Those findings may be indicative of a constant, negative OSA influence on the heart muscle repolarization stability.

Baumert et al in a retrospective study showed a correlation between QTV variance and OSA incidence in at least medium severity degree (24). However, the study group was smaller and even more heterogeneous in terms of age and body weight than in the presented study. Also, Viigimae et al, while examining OSA patients, observed a correlation between breathing disorders and QTV by analyzing different sleep stages (27). So far, there was no study concerning this problem conducted on a bigger than 50 patients group, with no less control group. In the study supervised by Gami data of over 10000 patients was analyzed; on its base OSA was identified as an independent risk factor for SCD (28). SCD among OSA patients is also more frequently observed at night than during the day, in contrast to the general SCD population (29). The results of the presented study may explain pathophysiology of this phenomenon.

Moreover, a gender percentage participation in groups of patients with and without OSA was assessed, in which a critically elongated QTc max was diagnosed (for both sexes $>500 \mathrm{~ms}$ ). It is shown that a critically elongated QTc max value was diagnosed more often among men with OSA than among men without this disease. A similar regularity was not observed among women. Therefore, it could mean that male gender additionally generates an adverse influence of OSA on heart muscle repolarization. All patients in whom a critically elongated QTc max was diagnosed were referred for further diagnostics.

An interesting result was also produced by the analysis of the influence of OSA temporal intensification on analyzed QT interval assessment parameters. There were 4-5 minutes lasting fragments of ECG records chosen, for which there were simultaneously recorded breathing disorders of minimum severity (or lack of them) for each patient. Subsequently, they were compared with, also 4-5 minutes lasting, fragments of ECG record of episodes of OSA of maximum intensification, for the same patient. A statistically significant difference for QTVi between episodes of minimum and maximum OSA intensification was noticed. It proves that there is an essential adverse influence, of even temporal OSA intensification, on heart muscle repolarization. Therefore, this result may explain results of the above mentioned studies, in which an increase of SCD incidence among 
OSA patients was shown especially during night time, when breathing disorders occur and get worse. Close to statistical significance also the result of the relationship between QTV calculated from analyzed ECG fragments has been placed. Therefore, a further evaluation of this dependence assessed on a bigger data would be interesting. The results of the above presented analysis may present an additional, next to continuous, negative influence of breathing disorders on heart muscle repolarization, appearing in moments of increased hypoxia. The analysis had a typically pilotage style. There are no similar calculations in available literature, analyzing a correlation between temporal OSA intensification on QT interval change.

Many, significant associations between the most important parameters from polygraphy (i.e. RDI, AI, ODI4\%, T90, minimum and average blood saturation) and QT interval assessment parameters were shown. Those associations applied to relationships between both quantitative and qualitative OSA intensification parameters, independently of age or body weight of patients. Those results prove that the number of hypoxia episodes, as well as their depth and duration, have a crucial influence on heart muscle repolarization processes homogeneity. The analysis for so many polygraphic parameters has not been carried out in literature yet.

\section{Limitations of the study:}

A relatively small number of examined population and its heterogeneity in terms of age and obesity degree may be perceived as a limitation of the study. Another limiting factor turned out to be the usage of Holter-ECG analyzing software, preventing QTV analysis in HRV of LF and HF band, which made an analysis of QT interval parameters, in the light of QTV assessment guidelines, incomplete (6). The last limiting factor is lack of a long-term observation of the examined population which could help to make more conclusions concerning the clinical significance of observed differences. However, a follow-up study after one and five years for mortality evaluation is planned.

\section{References:}

1. Report of a WHO Expert Consultation. Waist circumference and waist-hip ratio. Geneva, 8-11 Dec 2008.

2. Mathieu P., Poirier P. et al. Visceral obesity. The link among inflammation, hypertension and cardiovascular disease. Hypertension. 2009;53:577-594.

3. Arslan E., Yiginer O. et al. Effect of uncomplicated obesity on QT interval in young men. Pol Arch Med Wewn 2010, 120 (6): 209-213.

4. Mehra R., Benjamin E.J., Shahar E. i wsp. Association of nocturnal arrhytmias with sleep-disordered breathing: the Sleep Heart Health Study. Am. J. Respir. Crit. Care Med. 2006; 173:910-916.

5. Barta K., Szabó Z., Kun C., et al. The effect of sleep apnea on QT interval, QT dispersion, and arrhythmias. Clin Cardiol, 2010 Jun;33(6):E35-9.

6. Baumert M., Porta A. et al. QT interval variability in body surface ECG: measurement, physiological basis, and clinical value: position statement and 
consensus guidance endorsed by the European Heart Rhythm Association jointly with the ESC Working Group on Cardiac Cellular Electrophysiology. Europace (2016) 18, 925-944.

7. Vrtovec B., Starc V., et al. Beat-to-beat QT interval variability in coronary patients. J Electrocardiol 2000;33:119-25.

8. Murabayashi T., Fetics B., et al. Beat-to-beat QT interval variability associated with acute myocardial ischemia. J Electrocardiol 2002;35:19-25.

9. Sosnowski M., Czyż Z., i wsp. Time and frequency analysis of beat-to-beat R-T interval variability in patients with ischaemic left ventricular dysfunction providing evidence for non-neural control of ventricular repolarisation. Eur J Heart Fail 2002;4:737-43.

10. Myredal A., Karlsson A.K., et al. Elevated temporal lability of myocardial repolarization after coronary artery bypass grafting. J Electrocardiol 2008;41: 698702.

11. Myredal A., Gao S., et al. Increased myocardial repolarization lability and reduced cardiac baroreflex sensitivity in individuals with high-normal blood pressure. J Hypertens 2005;23:1751-6.

12. Baumert M., Schlaich M.P., et al. Relation between QT interval variability and cardiac sympathetic activity in hypertension. Am J Physiol Heart Circ Physiol 2011;300:H1412-17.

13. Hinterseer M., Beckmann B.M., et al. Relation of increased short-term variability of QT interval to congenital long-QT syndrome. Am J Cardiol 2009;103:1244-8.

14. Alam I., Lewis M.J., et al. Influence of bariatric surgery on indices of cardiac autonomic control. Auton Neurosci 2009;151:168-73.

15. Haigney M.C., Zareba W. et al. QT interval variability and spontaneous ventricular tachycardia or fibrillation in the Multicenter Automatic Defibrillator Implantation Trial (MADIT) II patients. J Am Coll Cardiol 2004;44:1481-7.

16. Woosley R.L., Romero K.A., www.Crediblemeds.org, QTdrugs List, [access date 05 May 2019, AZCERT, Inc. 1822 Innovation Park Dr., Oro Valley, AZ 85755.

17. Johns M. https://epworthsleepinessscale.com/about-the-ess/ [access date 08 May 2020.

18. https://www.who.int/ncds/surveillance/steps/en/. [access date 23 April.2019].

19. American Academy of Sleep Medicine. International classification of sleep disorders, 2nd ed. Diagnostic and coding manual. Westchester, Illinois: American Academy of Sleep Medicine 2005. Updated November 2015. Darien, IL: American Academy of Sleep medicine, 2016.

20. American Academy of Sleep Medicine. Sleep-related breathing disorders in adults: recommendations for syndrome definition and measurement techniques in clinical research: the report of an American Academy of Sleep Medicine Task Force. Sleep 1999; 22: 667-689.

21. Arslan E., Yiginer O. et al. Effect of uncomplicated obesity on QT interval in young men. Pol. Arch Med Wewn, 2010 Jun;120(6):209-13.

22. Papaioannou A., Michaloudis D. Effects of weight loss on QT interval in morbidly obese patients. Obes Surg. 2003 Dec;13(6):869-73. 
23. Strack C., Fessmann S. et al. QT prolongation is frequently observed in obesity with and without the metabolic syndrome and can be reversed by long term weight reduction.

24. Baumert M., Smith J. Variability of QT Interval Duration in Obstructive Sleep Apnea: An Indicator of Disease Severity. Sleep. 2008 Jul 1; 31(7): 959-966.

25. Romera-Corral A., Caples S.M. Interactions between obesity and obstructive sleep apnea. Implications for treatment. Chest. 2010 Mar; 137(3):711-719.

26. Menon A., Kumar M. Influence of Body Position on Severity of Obstructive Sleep Apnea: A Systematic Review. ISRN Otolaryngology Volume 2013, Article ID 670381.

27. Viigimae M., Karai D. QT interval variability index and QT interval duration during different sleep stages in patients with obstructive sleep apnea. Sleep Med. 2017 Sep;37:160-167.

28. Gami A.S., Olson E.J. Obstructive sleep apnea and the risk of sudden cardiac death: a longitudinal study of 10,701 adults. J Am Coll Cardiol. 2013 Aug 13;62(7):610-6.

29. Gami A.S., Howard D.E. Day-night pattern of sudden death in obstructive sleep apnea. N Engl J Med. 2005 Mar 24; 352(12):1206-14. 
medRxiv preprint doi: https://doi.org/10.1101/2020.07.22.20159657; this version posted July 24, 2020. The copyright holder for this preprint (which was not certified by peer review) is the author/funder, who has granted medRxiv a license to display the preprint in perpetuity. All rights reserved. No reuse allowed without permission.

Obstructive Sleep Apnea destabilizes myocardial repolarization homogeneity. Tabels.

Table 1. Overall characteristics of population with and without OSA.

\begin{tabular}{|c|c|c|c|c|c|c|c|}
\hline parameter & $\begin{array}{c}\text { OBS }(-) \\
\text { mean, SD }\end{array}$ & $\begin{array}{c}\text { OBS (-) } \\
\text { median, } \\
\text { min, max }\end{array}$ & & $\begin{array}{c}\text { OBS }(+) \\
\text { mean, SD }\end{array}$ & $\begin{array}{l}\text { OBS }(+) \\
\text { median, } \\
\text { min, max }\end{array}$ & p Ttest & $\begin{array}{c}\text { p } \\
\text { Wilcoxon }\end{array}$ \\
\hline age & $44,2 \pm 8,1$ & $\begin{array}{c}41(35- \\
65)\end{array}$ & & $49,7 \pm 8,9$ & $\begin{array}{c}50,5(35- \\
65)\end{array}$ & & $<0,001$ \\
\hline male sex & \multicolumn{2}{|c|}{$23(45,1 \%)$} & & \multicolumn{2}{|c|}{$41(58,6 \%)$} & \multicolumn{2}{|c|}{$\mathrm{p}=0,2$} \\
\hline BMI & $30,1 \pm 4,9$ & $\begin{array}{l}28,1(22,8 \\
-42,7)\end{array}$ & & $33,8 \pm 6,3$ & $\begin{array}{l}32,2(24,7 \\
\quad-58,7)\end{array}$ & $<0,001$ & \\
\hline waist & $103,2 \pm 10$ & $\begin{array}{c}101(86- \\
129)\end{array}$ & & $\begin{array}{c}113,7 \pm \\
15,1\end{array}$ & $\begin{array}{c}112(85- \\
154)\end{array}$ & & $<0,001$ \\
\hline neck & $39,8 \pm 3,5$ & $\begin{array}{c}40(32- \\
47)\end{array}$ & & $42,8 \pm 4,3$ & $\begin{array}{l}42,5(33- \\
55)\end{array}$ & & $<0,001$ \\
\hline $\begin{array}{l}\text { corrected } \\
\text { neck }\end{array}$ & $41,4 \pm 4,2$ & $41(32-49)$ & & $46,2 \pm 4,9$ & $\begin{array}{c}46(36- \\
60)\end{array}$ & $<0,001$ & \\
\hline $\begin{array}{c}\text { RDI } \\
\text { degree }\end{array}$ & \multicolumn{2}{|c|}{$\begin{array}{c}51(100 \%) / 0(0 \%) / 0 \\
(0 \%) / 0(0 \%)\end{array}$} & & \multicolumn{2}{|c|}{$\begin{array}{c}47(67,1 \%) / 14(20 \%) / \\
2(2,9) / 7(10 \%)\end{array}$} & \multicolumn{2}{|c|}{$\mathrm{p}<0,001$} \\
\hline QTe $\max 1$ & $\begin{array}{c}447,6 \pm \\
22,3\end{array}$ & $\begin{array}{l}444(400- \\
482)\end{array}$ & $\begin{array}{l}\text { QTe max } \\
2\end{array}$ & $\begin{array}{c}449,7 \pm \\
23,5\end{array}$ & $\begin{array}{l}448(406- \\
510)\end{array}$ & & 0,56 \\
\hline QTV 1 & $0,7 \pm 0,4$ & $\begin{array}{c}0,7(0- \\
2,3)\end{array}$ & QTV 2 & $4,5 \pm 4,1$ & $\begin{array}{c}2,8(0,8- \\
22,9)\end{array}$ & $<0,001$ & \\
\hline QTVi 1 & $-3,6 \pm 0,4$ & $\begin{array}{c}-3,5(-5,4- \\
-2,8)\end{array}$ & QTVi 2 & $-2,7 \pm 0,4$ & \begin{tabular}{|c|}
$-2,8(-3,4-$ \\
$-1,9)$
\end{tabular} & $<0,001$ & \\
\hline QTc $\max 1$ & $\begin{array}{c}447,6 \pm \\
22,3\end{array}$ & $\begin{array}{l}444(400- \\
482)\end{array}$ & $\begin{array}{l}\text { QTc max } \\
\mathbf{3}\end{array}$ & $\begin{array}{c}449,7 \pm \\
26,3\end{array}$ & $\begin{array}{l}444,5(405 \\
-507)\end{array}$ & & 0,84 \\
\hline QTV 1 & $0,7 \pm 0,4$ & $\begin{array}{c}0,7(0- \\
2,3)\end{array}$ & QTV 3 & $5 \pm 3$ & $\begin{array}{c}4,2(0,8- \\
17,8)\end{array}$ & & $<0,001$ \\
\hline QTVi 1 & $-3,6 \pm 0,4$ & $\begin{array}{c}-3,5(-5,4- \\
-2,8)\end{array}$ & QTVi 3 & $-2,6 \pm 0,3$ & $\begin{array}{c}-2,6(-3,2- \\
-1,8)\end{array}$ & & $<0,001$ \\
\hline HR mean & $68,1 \pm 9,8$ & 69 (66 - & & $69 \pm 9,1$ & $67(60-$ & 0,62 & \\
\hline
\end{tabular}




\begin{tabular}{|c|c|c|c|c|c|c|}
\hline & & 88) & & 91) & & \\
\hline QTe max & $\begin{array}{c}480,3 \pm \\
26,6\end{array}$ & $\begin{array}{c}474(426- \\
567)\end{array}$ & $\begin{array}{c}484,6 \pm \\
26,4\end{array}$ & $\begin{array}{c}485(439- \\
562)\end{array}$ & 0,37 & \\
\hline sodium & $141 \pm 2,5$ & $\begin{array}{c}141(135- \\
147)\end{array}$ & $141,8 \pm 2,5$ & $\begin{array}{c}142(136- \\
147)\end{array}$ & 0,09 & \\
\hline potassium & $4,4 \pm 0,4$ & $\begin{array}{c}4,3(3,8- \\
5,7)\end{array}$ & $4,3 \pm 0,3$ & $\begin{array}{c}4,2(3,4- \\
5,2)\end{array}$ & 0,13 & \\
\hline calcium & $2,3 \vee 0,1$ & $\begin{array}{c}2,4(2- \\
2,5)\end{array}$ & $2,3 \pm 0,1$ & $\begin{array}{c}2,3(2- \\
2,7)\end{array}$ & & 0,25 \\
\hline magnesium & $0,9 \pm 0,1$ & $\begin{array}{c}0,9(0,7- \\
1)\end{array}$ & $0,9 \pm 0,2$ & $\begin{array}{c}0,8(0,7- \\
1,9)\end{array}$ & 0,33 & \\
\hline glucose & $94,1 \pm 4,6$ & $\begin{array}{c}94,7(83,2 \\
-99,7)\end{array}$ & $95,5 \pm 5$ & $\begin{array}{c}98(82,1- \\
99)\end{array}$ & 0,11 & \\
\hline
\end{tabular}

Source: Own study results.

Table 2. A linear regression for a relationship between the QTe max and RDI variables.

\begin{tabular}{|c|c|c|c|c|c|c|}
\hline QTc max 1 & Coef. & Std. Err. & $\mathbf{t}$ & \multicolumn{2}{|c|}{ P>|t| } & \multicolumn{2}{|c|}{ [95\% Conf. Interval] } \\
\hline RDI & .187138 & .0886293 & 2,11 & 0,037 & .011643 & .3626329 \\
_cons & 445,6936 & 2,526937 & 176,38 & 0,000 & 440,69 & 450,6972 \\
\hline
\end{tabular}

Source: Own study results.

Table 3. A linear regression results describing a relationship between QTV and RDI variables.

\begin{tabular}{|c|c|c|c|c|c|c|}
\hline QTV 1 & Coef. & Std. Err. & $\mathbf{t}$ & \multicolumn{2}{|c|}{$\mathbf{P}>|\mathbf{t}|$} & \multicolumn{2}{|c|}{ [95\% Conf. Interval] } \\
RDI & .038734 & .0140009 & 2,77 & 0,007 & .0110109 & .0664571 \\
\hline _cons & 2,2877737 & .3991824 & 5,73 & 0,000 & 1,497316 & 3,078158 \\
\hline
\end{tabular}

Source: Own study results.

Table 4. A linear regression results describing a relationship between QTVi and RDI 
variables.

\begin{tabular}{|c|c|c|c|c|c|c|} 
QTVi 1 & Coef. & Std. Err. & $\mathbf{t}$ & \multicolumn{2}{|c|}{$\mathbf{P}>|\mathbf{t}|$} & \multicolumn{2}{|c|}{$[\mathbf{9 5 \%}$ Conf. Interval] } \\
\hline RDI & .0111336 & .0019982 & 5,57 & 0,000 & .0071769 & .0150902 \\
_cons & $-3,249741$ & .0569713 & $-57,04$ & 0,000 & $-3,36255$ & $-3,136932$ \\
\hline
\end{tabular}

Source: Own study results.

Table 5. Comparative characteristics of groups with different OSA's severity degree.

\begin{tabular}{|c|c|c|c|c|c|c|c|c|}
\hline & $\begin{array}{c}\text { RDI 1, } \\
\text { mean, } \\
\text { SD }\end{array}$ & $\begin{array}{c}\text { RDI 1, } \\
\text { median, } \\
\text { min, } \\
\text { max }\end{array}$ & $\begin{array}{l}\text { RDI } 2 \text {, } \\
\text { mean, } \\
\text { SD }\end{array}$ & $\begin{array}{c}\text { RDI 2, } \\
\text { median, } \\
\text { min, } \\
\text { max }\end{array}$ & $\begin{array}{c}\text { RDI 3, } \\
\text { mean, } \\
\text { SD }\end{array}$ & $\begin{array}{c}\text { RDI 3, } \\
\text { median, } \\
\text { min, } \\
\text { max }\end{array}$ & pANOVA & $\begin{array}{c}\text { pKruskal- } \\
\text { Walis }\end{array}$ \\
\hline $\begin{array}{c}\mathrm{SpO2} \\
\min \end{array}$ & $83 \pm 3,5$ & $\begin{array}{c}84(74- \\
89)\end{array}$ & $\begin{array}{c}81,1 \pm \\
3,1\end{array}$ & $\begin{array}{c}80,5(76- \\
87)\end{array}$ & $\begin{array}{c}72,2 \pm \\
8,8\end{array}$ & 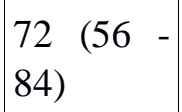 & $<0,001$ & \\
\hline SpO2 av & $\begin{array}{c}92,8 \pm \\
1,7\end{array}$ & $\begin{array}{c}93,2(89- \\
95,5)\end{array}$ & $\begin{array}{c}92,2 \pm \\
1,7\end{array}$ & $\begin{array}{c}92,6 \\
(88,8- \\
95,8)\end{array}$ & $\begin{array}{c}90,1 \pm \\
4,8\end{array}$ & $\begin{array}{c}91,9 \\
(75,2- \\
94,9)\end{array}$ & 0,009 & \\
\hline ODI4\% & $9,8 \pm 1,7$ & $\begin{array}{c}8,6(4- \\
22,4)\end{array}$ & $\begin{array}{c}26,3 \pm \\
16,9\end{array}$ & $\begin{array}{c}22,5 \\
(11,7- \\
89,8)\end{array}$ & $\begin{array}{c}62,9 \pm \\
28,4\end{array}$ & $\begin{array}{c}52,4 \\
(21,2- \\
132,5)\end{array}$ & $<0,001$ & \\
\hline T90 & $\begin{array}{c}7,3 \pm \\
12,9\end{array}$ & $\begin{array}{c}1,4(0- \\
53,1)\end{array}$ & $\begin{array}{c}10,3 \pm \\
15,6\end{array}$ & $\begin{array}{c}5,7(0,4- \\
65,6)\end{array}$ & $28 \pm 27,3$ & $\begin{array}{c}17,9(1,4 \\
-89,2)\end{array}$ & & $<0,001$ \\
\hline RDI & $9,3 \pm 3,2$ & $\begin{array}{c}8,7(5,2- \\
14,8)\end{array}$ & $\begin{array}{c}21,5 \pm \\
4,7\end{array}$ & $\begin{array}{c}21,3 \\
(15,6- \\
29,8)\end{array}$ & $\begin{array}{c}60,9 \pm \\
25,3\end{array}$ & $\begin{array}{c}55,9 \\
(31,4- \\
133,6)\end{array}$ & & $<0,001$ \\
\hline AI & $0,4 \pm 0,7$ & $\begin{array}{c}0(0- \\
3,2)\end{array}$ & $3,7 \pm 4,4$ & $\begin{array}{l}2(0- \\
16,8)\end{array}$ & $\begin{array}{c}17,1 \pm \\
21,5\end{array}$ & $\begin{array}{l}8(0- \\
82,2)\end{array}$ & & $<0,001$ \\
\hline $\begin{array}{c}\text { QTe max } \\
2\end{array}$ & $\begin{array}{c}445 \pm \\
20,2\end{array}$ & $\begin{array}{c}446(406 \\
-510)\end{array}$ & $\begin{array}{c}451,1 \pm \\
23,5\end{array}$ & $\begin{array}{c}448(412 \\
-493)\end{array}$ & $\begin{array}{c}455,8 \pm \\
27,9\end{array}$ & $\begin{array}{c}458(406 \\
-500)\end{array}$ & 0,26 & \\
\hline QTV 2 & $5,1 \pm 5,3$ & $\begin{array}{c}2,8(0,8- \\
22,9)\end{array}$ & $3,2 \pm 1,8$ & $\begin{array}{c}2,7(0,8- \\
7,5)\end{array}$ & $4,8 \pm 3,5$ & $\begin{array}{c}3,1(1,1- \\
15)\end{array}$ & & 0,27 \\
\hline QTVi 2 & $-2,8 \pm 0,4$ & $\begin{array}{c}-2,8(-3,3 \\
--1,9)\end{array}$ & $-2,8 \pm 0,2$ & $\begin{array}{c}-2,8(-3,4 \\
--2,4)\end{array}$ & $-2,8 \pm 0,4$ & $\begin{array}{c}-2,6(-3,4 \\
--1,9)\end{array}$ & 0,15 & \\
\hline
\end{tabular}


medRxiv preprint doi: https://doi.org/10.1101/2020.07.22.20159657; this version posted July 24, 2020. The copyright holder for this preprint (which was not certified by peer review) is the author/funder, who has granted medRxiv a license to display the preprint in perpetuity. All rights reserved. No reuse allowed without permission.

\begin{tabular}{|c|c|c|c|c|c|c|c|c|}
\hline $\begin{array}{c}\text { QTe max } \\
3\end{array}$ & $\begin{array}{c}447,4 \pm \\
26,7\end{array}$ & $\begin{array}{c}436(405 \\
-502)\end{array}$ & $\begin{array}{c}448,4 \pm \\
25\end{array}$ & $\begin{array}{c}445(406 \\
-479)\end{array}$ & $\begin{array}{c}454,6 \pm \\
27,6\end{array}$ & $\begin{array}{c}452,45 \\
(405- \\
507)\end{array}$ & & 0,43 \\
\hline QTV 3 & $4,9 \pm 3,2$ & $\begin{array}{c}4,2((0,8 \\
-17,8)\end{array}$ & $4,4 \pm 2,8$ & $\begin{array}{c}3,4(1,7- \\
12,2)\end{array}$ & $59 \pm 2,8$ & $\begin{array}{c}6,1(2- \\
12,7)\end{array}$ & & 0,1 \\
\hline QTVi 3 & $-2,6 \pm 0,3$ & $\begin{array}{c}-2,6(-3,2 \\
--1,8)\end{array}$ & $-2,6 \pm 0,3$ & $\begin{array}{c}-2,6(03- \\
-2)\end{array}$ & $\begin{array}{c}02,6 \pm \\
0,3\end{array}$ & $\begin{array}{c}-2,6(-3,2 \\
--2)\end{array}$ & 0,97 & \\
\hline $\begin{array}{c}\text { HR } \\
\text { mean }\end{array}$ & $\begin{array}{c}67,1 \pm \\
9,1\end{array}$ & $\begin{array}{c}66,5(50- \\
90)\end{array}$ & $\begin{array}{c}69,1 \pm \\
7,9\end{array}$ & $\begin{array}{c}69,5(53- \\
86)\end{array}$ & $\begin{array}{c}71,8 \pm \\
9,6\end{array}$ & $\begin{array}{c}68,5(61- \\
91)\end{array}$ & & 0,3 \\
\hline QTe max & $\begin{array}{c}482,3 \pm \\
26,3\end{array}$ & $\begin{array}{c}477(439 \\
-555)\end{array}$ & $\begin{array}{c}481,9 \pm \\
23,4\end{array}$ & $\begin{array}{c}483,5 \\
(441- \\
521)\end{array}$ & $\begin{array}{c}490,8 \mathrm{v} \\
29,3\end{array}$ & $\begin{array}{c}489(448 \\
-562)\end{array}$ & 0,47 & \\
\hline $\mathbf{N a}$ & $\begin{array}{c}141,4 \pm \\
2,5\end{array}$ & $\begin{array}{c}142(136 \\
-146)\end{array}$ & $\begin{array}{c}142,3 \pm \\
2,8\end{array}$ & $\begin{array}{c}142(137 \\
-147)\end{array}$ & $\begin{array}{c}11,8 \pm \\
2,3\end{array}$ & $\begin{array}{c}142(138 \\
-146)\end{array}$ & 0,5 & \\
\hline $\mathbf{K}$ & $4,4 \pm 0,3$ & $\begin{array}{c}4,3(3,8- \\
5,2)\end{array}$ & $4,2 \pm 0,3$ & $\begin{array}{c}4,2(3,6- \\
4,8)\end{array}$ & $4,2 \pm 0,3$ & $\begin{array}{c}4,2(3,4- \\
4,8)\end{array}$ & 0,3 & \\
\hline $\mathbf{C a}$ & $2,3 \pm 0,1$ & $\begin{array}{c}2,3(2- \\
2,6)\end{array}$ & $2,3 \pm 0,1$ & $\begin{array}{c}2,3(2,1- \\
2,5)\end{array}$ & $2,3 \pm 0,2$ & $\begin{array}{c}2,3(2- \\
2,7)\end{array}$ & 0,36 & \\
\hline Mg & $0,9 \pm 0,2$ & $\begin{array}{c}0,9(0,7- \\
1,9)\end{array}$ & $0,9 \pm 0,3$ & $\begin{array}{c}0,8(0,8- \\
1,9)\end{array}$ & $0,8 \pm 0,1$ & $\begin{array}{c}0,8(0,7- \\
1)\end{array}$ & 0,49 & \\
\hline glucose & $\begin{array}{c}95,2 \pm \\
4,9\end{array}$ & $\begin{array}{c}98(84- \\
99)\end{array}$ & $\begin{array}{c}95,9 \pm \\
4,6\end{array}$ & $\begin{array}{c}98(84- \\
99)\end{array}$ & $\mid \begin{array}{ll}95,5 & \pm \\
5,7 & \end{array}$ & $\begin{array}{c}99(82,1- \\
99)\end{array}$ & 0,88 & \\
\hline
\end{tabular}

Source: Own study results.

Table 6. Results of QT interval assessment parameters analysis according to a temporary OSA's intensification.

\begin{tabular}{|c|c|c|c|c|}
\hline & median & minimum & maximum & $\mathrm{p}$ Wilcoxon \\
\hline QTc max 2 [ms] & 448 & 406 & 510 & $\mathrm{p}=0,91$ \\
QTc max 3 [ms] & 444 & 405 & 507 & \\
\hline QTV 2 & 2,83 & 0,85 & 22,91 & $\mathrm{p}=0,06$ \\
\hline QTV 3 & 4,24 & 0,85 & 17,82 & \\
QTVi 2 & $-2,77$ & $-3,38$ & $-1,87$ & $\mathrm{p}=0,008$ \\
\hline
\end{tabular}


QTVi 3

$-2,57$

Source: Own study results.

Table 7. A multifactor regression analysis of polygraphic and QT interval analysis parameters results.

\begin{tabular}{|c|c|c|c|c|c|c|}
\hline parameter & RDI & AI & ODI4\% & T90 & SpO2 min & $\mathrm{SpO2} \mathrm{av}$ \\
\hline \multirow[t]{2}{*}{ QTe max } & $\begin{array}{l}\mathrm{p}=0,004 \\
\mathrm{R} 2=0,22\end{array}$ & $\begin{array}{l}\mathrm{p}=0,056 \\
\mathrm{R} 2=0,16\end{array}$ & $\begin{array}{l}\mathrm{p}=0,005 \\
\mathrm{R} 2=0,21\end{array}$ & $\begin{array}{l}\mathrm{p}=0,63 \\
\mathrm{R} 2=0,11\end{array}$ & $\begin{array}{l}\mathrm{p}=0,12 \\
\mathrm{R} 2=0,14\end{array}$ & $\begin{array}{l}\mathrm{p}=0,71 \\
\mathrm{R} 2=0,11\end{array}$ \\
\hline & $\begin{array}{l}\text { age } 0,77 \\
\text { BMI } 0,58\end{array}$ & $\begin{array}{l}\text { age } 0,9 \\
\text { BMI } 0,18\end{array}$ & $\begin{array}{l}\text { age } 0,84 \\
\text { BMI } 0,5\end{array}$ & $\begin{array}{l}\text { age } 0,99 \\
\text { BMI } 0,16\end{array}$ & $\begin{array}{l}\text { age } 0,88 \\
\text { BMI } 0,29\end{array}$ & $\begin{array}{l}\text { age } 0,97 \\
\text { BMI } 0,17\end{array}$ \\
\hline \multirow[t]{2}{*}{ QTe max 2} & $\mathrm{p}=0,002$ & $\mathrm{p}=0,008$ & $\mathrm{p}=0,01$ & $\mathrm{p}=0,21$ & $\mathrm{p}=0,002$ & $\mathrm{p}=0,12$ \\
\hline & $\begin{array}{l}\mathrm{R} 2=0,23 \\
\text { age } 0,67\end{array}$ & $\begin{array}{l}\mathrm{R} 2=0,23 \\
\text { age } 0,99\end{array}$ & $\begin{array}{l}\mathrm{R} 2=0,22 \\
\text { age } 0,73\end{array}$ & $\begin{array}{l}\mathrm{R} 2=0,16 \\
\text { age } 0,81\end{array}$ & $\begin{array}{l}\mathrm{R} 2=0,26 \\
\text { age } 0,6\end{array}$ & $\begin{array}{l}\mathrm{R} 2=0,66 \\
\text { age } 0,66\end{array}$ \\
\hline \multirow[t]{2}{*}{ QTc $\max 3$} & $\begin{array}{l}\text { BMI } 0,54 \\
p=0,04 \\
\text { R2 }=0,21\end{array}$ & $\begin{array}{l}\text { BMI 0,2 } \\
p=0,13 \\
\text { R2 }=0,19\end{array}$ & $\begin{array}{l}\text { BMI } 0,45 \\
p=0,06 \\
\text { R2 }=0,2\end{array}$ & $\begin{array}{l}\text { BMI } 0,23 \\
p=0,56 \\
\text { R2 }=0,16\end{array}$ & $\begin{array}{l}\text { BMI } 0,53 \\
p=0,1 \\
\text { R2 }=0,19\end{array}$ & $\begin{array}{l}\text { BMI } 0,31 \\
p=0,37 \\
\text { R2 }=0,17\end{array}$ \\
\hline & $\begin{array}{l}\text { age } 0,5 \\
\text { BMI } 0,1\end{array}$ & $\begin{array}{l}\text { age } 0,34 \\
\text { BMI } 0,02\end{array}$ & $\begin{array}{l}\text { age } 0,46 \\
\text { BMI } 0,07\end{array}$ & $\begin{array}{l}\text { age } 0,41 \\
\text { BMI } 0,03\end{array}$ & $\begin{array}{l}\text { age } 0,49 \\
\text { BMI } 0,06\end{array}$ & $\begin{array}{l}\text { age } 0,5 \\
\text { BMI } 0,04\end{array}$ \\
\hline \multirow[t]{3}{*}{ QTV 2} & $\mathrm{p}=0,67$ & $\mathrm{p}=0,37$ & $\mathrm{p}=0,85$ & $\mathrm{p}=0,17$ & $\mathrm{p}=0,77$ & $\mathrm{p}=0,21$ \\
\hline & $\begin{array}{l}\mathrm{R} 2=0,08 \\
\text { age } 0,05\end{array}$ & $\begin{array}{l}\mathrm{R} 2=0,09 \\
\text { age } 0,06\end{array}$ & $\begin{array}{l}\mathrm{R} 2=0,08 \\
\text { age } 0,05\end{array}$ & $\begin{array}{l}\mathrm{R} 2=0,1 \\
\text { age } 0,04\end{array}$ & $\begin{array}{l}\mathrm{R} 2=0,08 \\
\text { age } 0,05\end{array}$ & $\begin{array}{l}\mathrm{R} 2=0,1 \\
\text { age } 0,03\end{array}$ \\
\hline & $\begin{array}{l}\text { BMI 0,06 } \\
p=0,03\end{array}$ & $\begin{array}{l}\text { BMI } 0,05 \\
p=0,03\end{array}$ & $\begin{array}{l}\text { BMI } 0,05 \\
p=0,02\end{array}$ & $\begin{array}{l}\text { BMI } 0,04 \\
p=0,47\end{array}$ & $\begin{array}{l}\text { BMI } 0,05 \\
p=0,07\end{array}$ & $\begin{array}{l}\text { BMI } 0,03 \\
p=0,9\end{array}$ \\
\hline
\end{tabular}


medRxiv preprint doi: https://doi.org/10.1101/2020.07.22.20159657; this version posted July 24, 2020. The copyright holder for this preprint (which was not certified by peer review) is the author/funder, who has granted medRxiv a license to display the preprint in perpetuity. All rights reserved. No reuse allowed without permission.

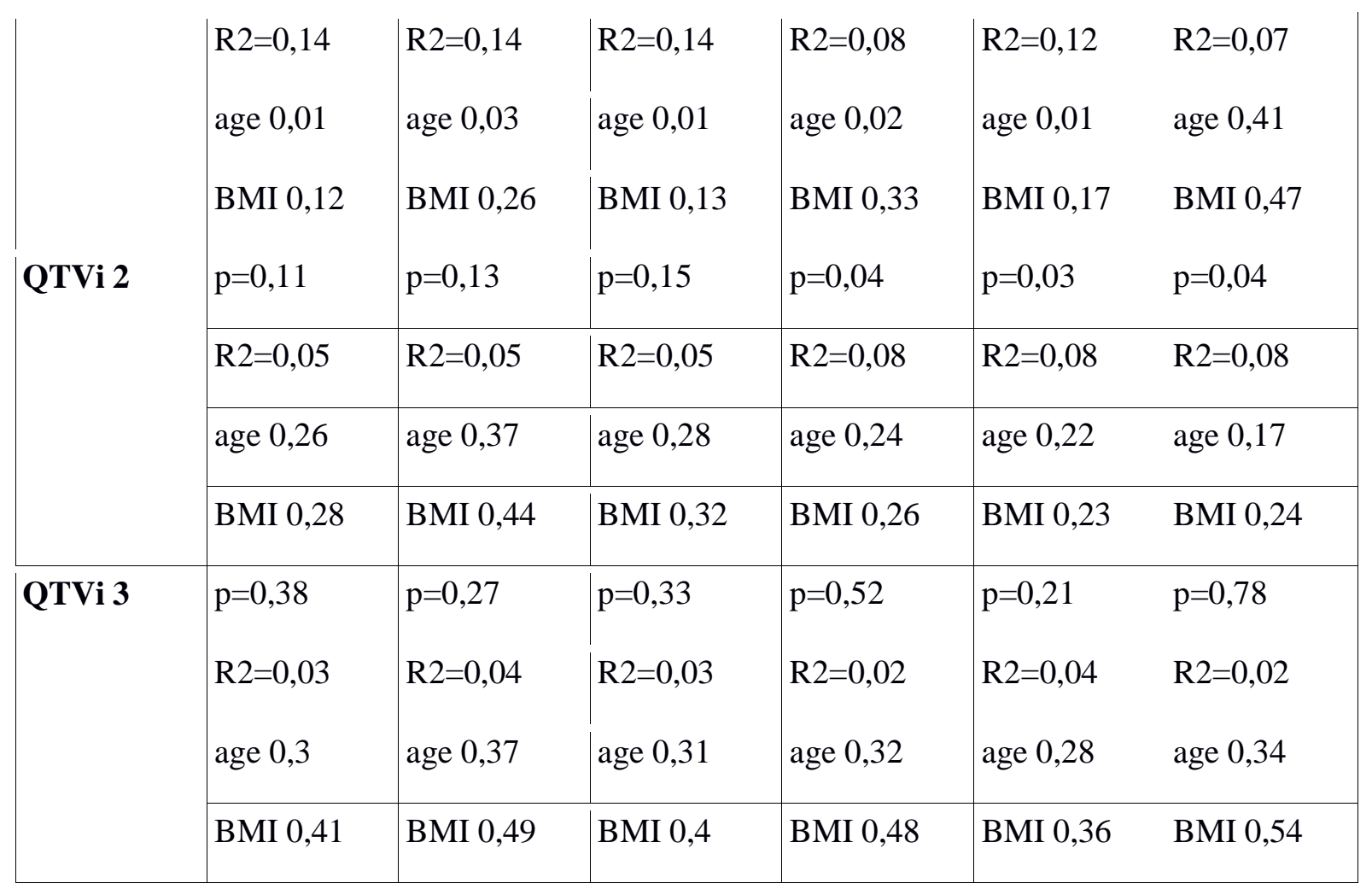

Source: Own study results. 
medRxiv preprint doi: https://doi.org/10.1101/2020.07.22.20159657; this version posted July 24, 2020. The copyright holder for this preprint (which was not certified by peer review) is the author/funder, who has granted medRxiv a license to display the preprint in perpetuity.

All rights reserved. No reuse allowed without permission.

\section{Obstructive Sleep Apnea destabilizes myocardial repolarization homogeneity. Figures.}

Figure 1. Averages, SE and 95\% CI for QTc max in studied OSA positive and negative groups (OSA+ and OSA-).

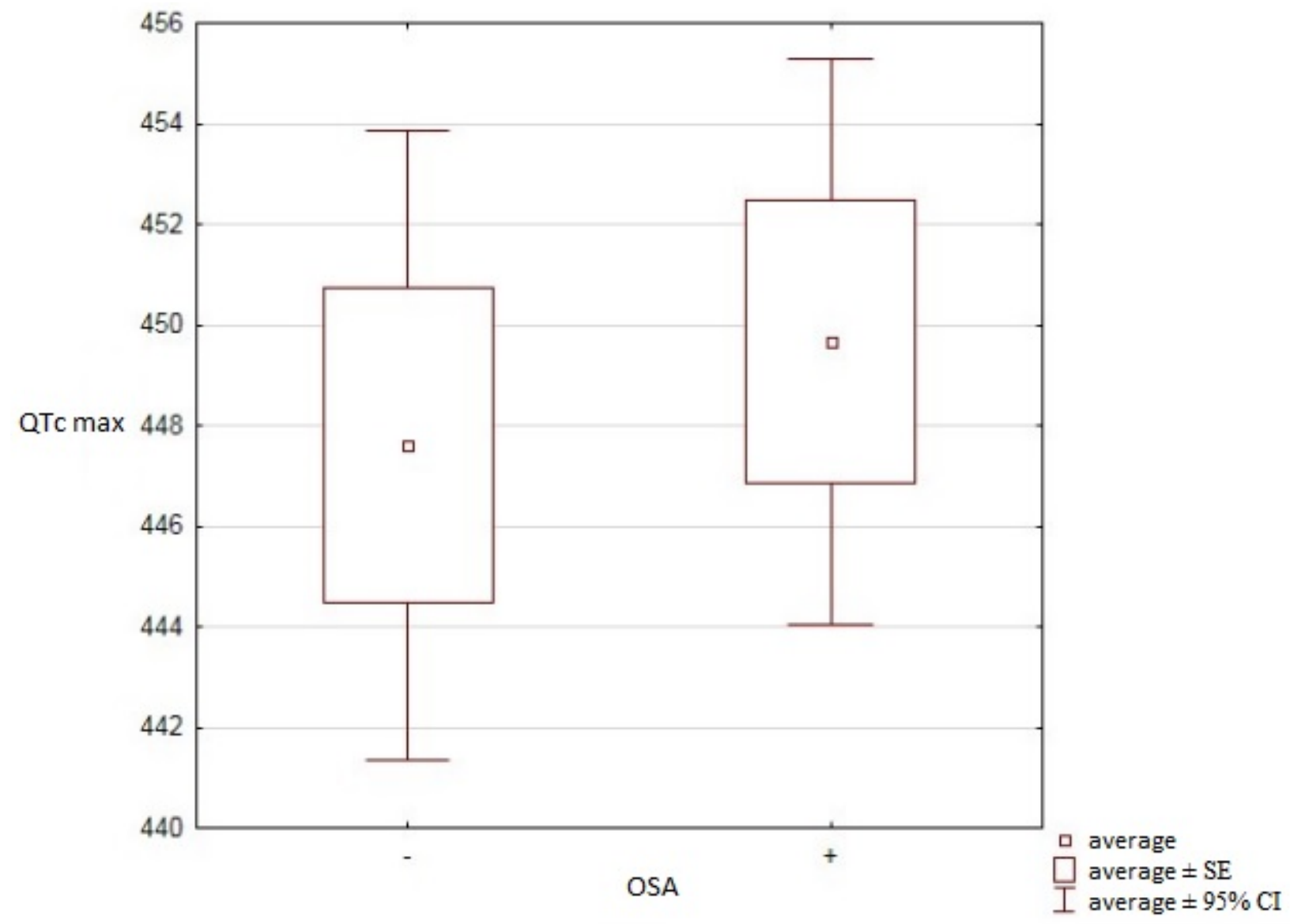

Source: Own study results. 
medRxiv preprint doi: https://doi.org/10.1101/2020.07.22.20159657; this version posted July 24, 2020. The copyright holder for this preprint (which was not certified by peer review) is the author/funder, who has granted medRxiv a license to display the preprint in perpetuity.

All rights reserved. No reuse allowed without permission.

Figure 2. Arithmetic averages, SE and $95 \%$ CI for QTC max between patients with OSA of $1^{\text {st }}, 2^{\text {nd }}$ and $3^{\text {rd }}$ severity degree.

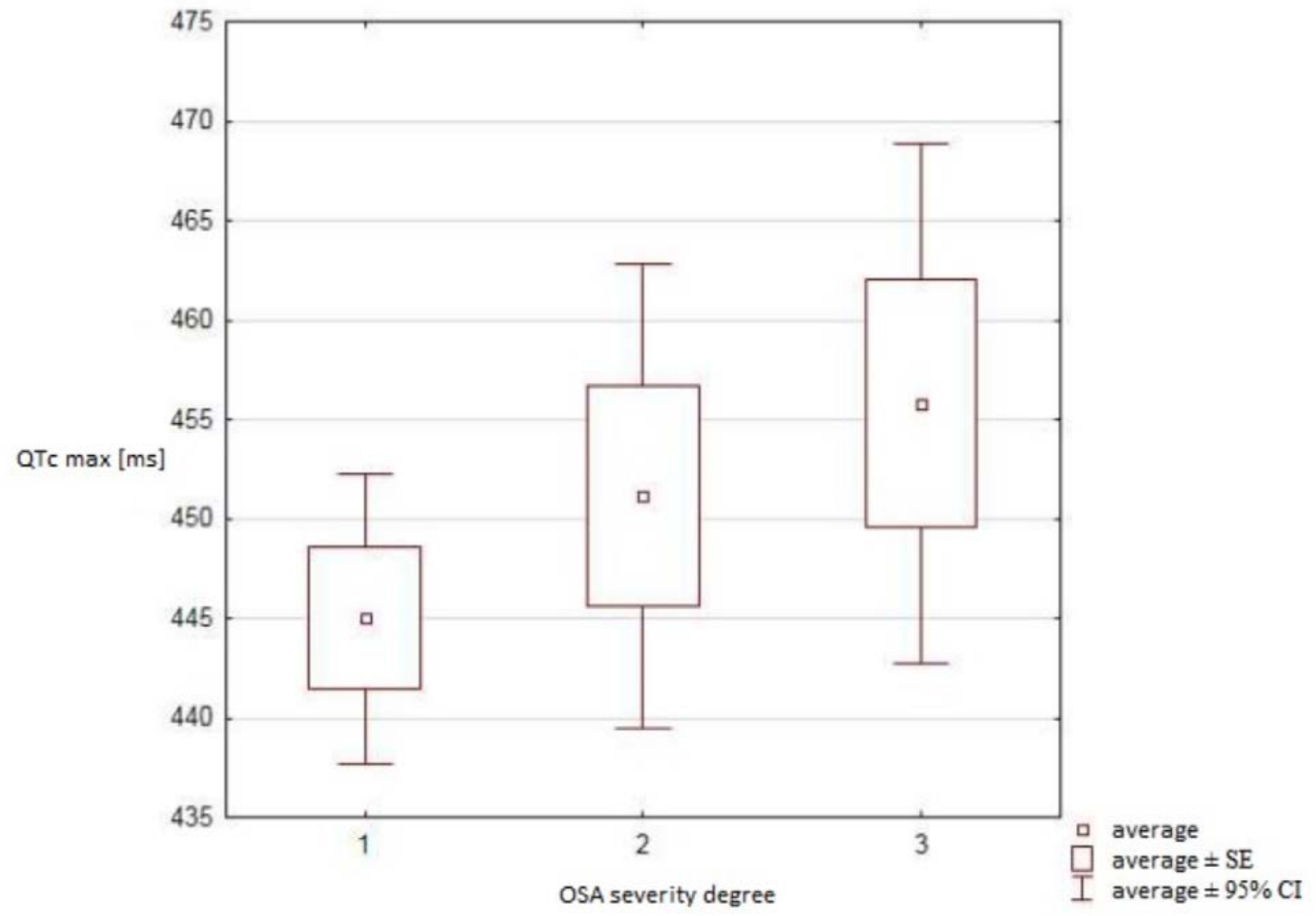

Source: Own study results. 
medRxiv preprint doi: https://doi.org/10.1101/2020.07.22.20159657; this version posted July 24, 2020. The copyright holder for this preprint (which was not certified by peer review) is the author/funder, who has granted medRxiv a license to display the preprint in perpetuity.

All rights reserved. No reuse allowed without permission.

Figure 3. A scatter chart presenting a relationship between the QTe max and RDI variables.

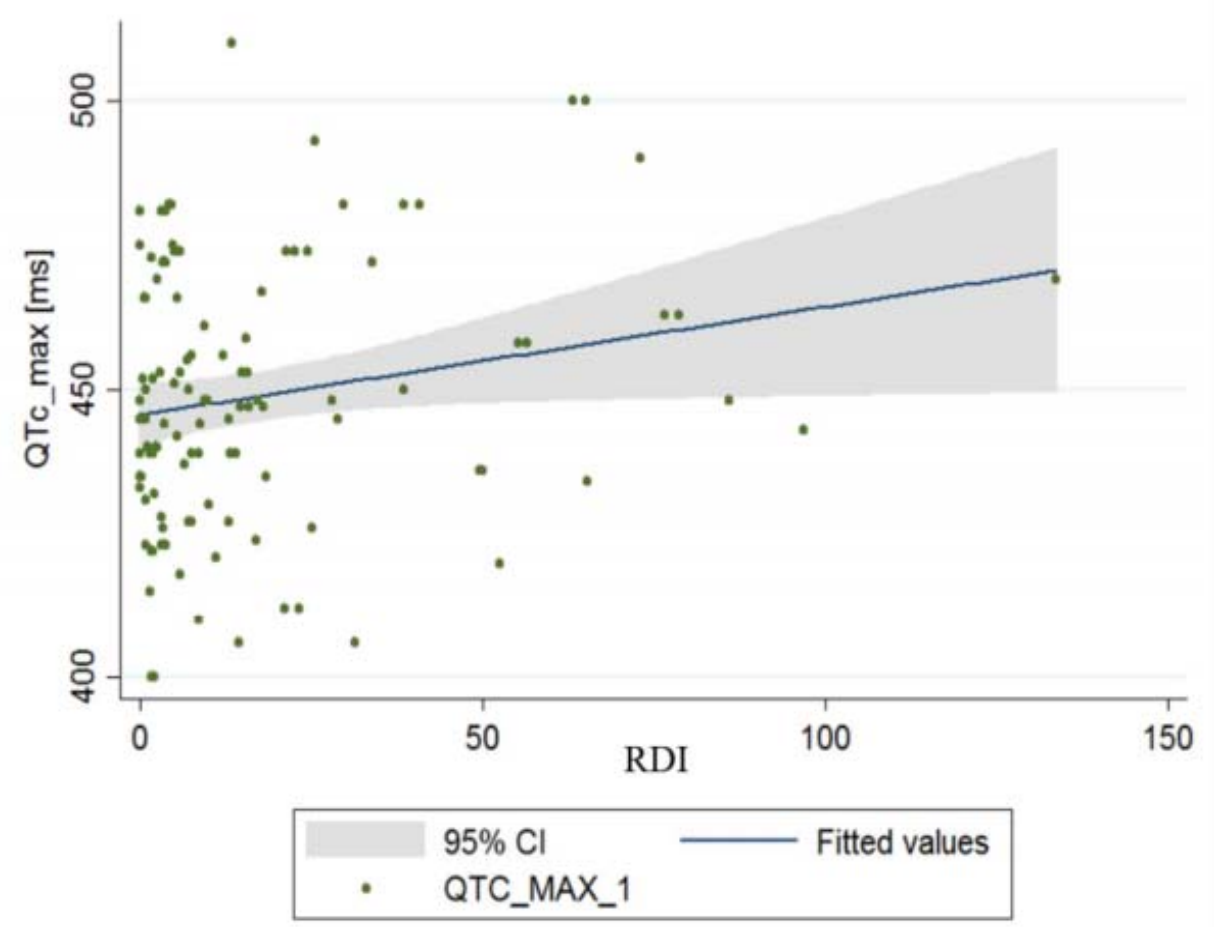

Source: Own study results. 
medRxiv preprint doi: https://doi.org/10.1101/2020.07.22.20159657; this version posted July $24,2020$. The copyright holder for this preprint (which was not certified by peer review) is the author/funder, who has granted medRxiv a license to display the preprint in perpetuity.

All rights reserved. No reuse allowed without permission.

Figure 4. Percentage of patients with critically elongated QTe max interval in studied groups of patients.

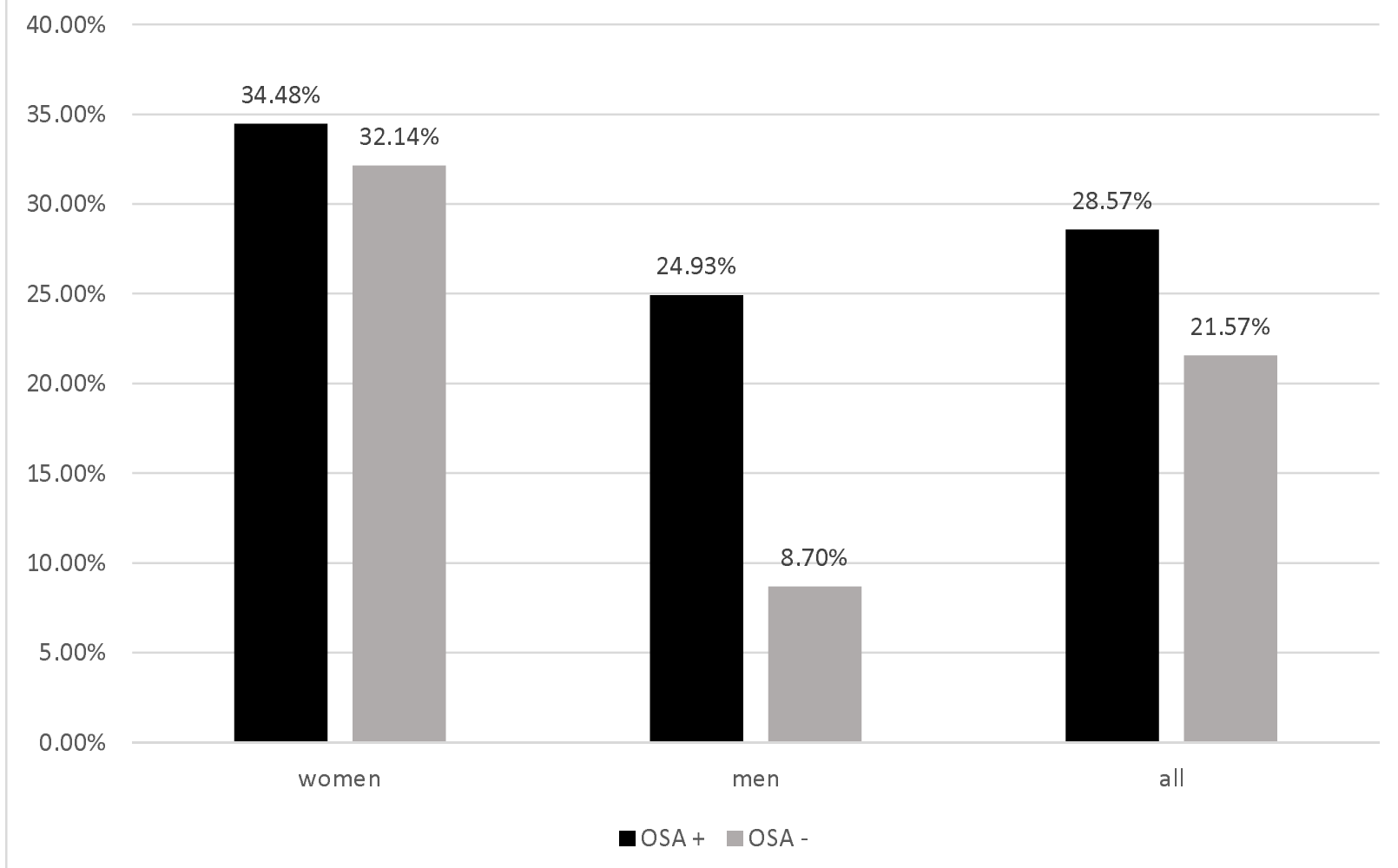

Source: Own study results. 